\title{
Cinematic and Aesthetic Cartographies of Subjective Mutation
}

Michael Goddard, University of Salford

\section{Introduction}

The recent works by Franco ‘Bifo' Berardi, especially Precarious Rhapsody, suggest a profound mutation of human subjectivity under the pressure of the imposition of a range of technical automatisms of which the digital is the latest and the one which has the most profound effects. Berardi proposes that 'video-electronic' and 'digital-connective' generations have emerged whose affects and perceptions have been profoundly disturbed by the implantation of digital technologies in all spheres of life. What is less frequently remarked on in Berardi's work is that the diagnosis of these mutations of subjectivity are frequently carried out in relation to the artistic cartographies generated by both film and media art, with a tendency to favour the former. For example, there are frequent references in Berardi's work to Bergman's The Serpent's Egg (1977) and Gus van Sant's Elephant (2003), to give only two examples.

In this essay I aim to look more closely at these and other examples and how they function as cartographies mapping at once the transformations of labour and subjectivity under postfordist conditions. I then aim to extend this through an engagement with the recent film, The Social Network (2010), which can be read as a direct mapping of contemporary affective mutation in the context of 21st Century cognitive capitalism. I will argue that there are elements of these cinematic cartographies that call into question some aspects of Berardi's diagnosis of contemporary subjective mutations, particularly the idea that they are necessarily associated with logics of technical acceleration and the destruction of affective relations with others. This diagnosis seems both predicated on ideas of cyberspatial disembodiment and to contain a latent humanism (the idea that a catastrophe will result from children learning language form a machine rather than from their mother epitomises this humanist dimension), that are complicated by the contemporary socialisation of digital culture in the so-called Web 2.0 era. This is not to say that the relations between humans and machines are not prone to the multiple pathologies diagnosed by Berardi but rather that these relations have taken on new forms and therefore will have different effects on subjectivity, than those attributed by Berardi to acceleration and disembodiment. It might be more fruitful in this context to follow other lines in Berardi's work such as the ideas of the intensive implantation of technical automatisms, following market logics directly within quotidian subjectivation processes. I will argue that these films suggest these other tendencies of contemporary subjective mutation, potentials that may lead not only to new pathologies but also to new social antagonisms, subjectivities and modes of expression.

\section{Cinema as Symptom Versus Deleuzian Symptomatology}

It is truism of film theory, especially of a psychoanalytic or structuralist variety, that cinema functions as a cultural symptom. This goes back to Freud's initial readings of works of art as the symptoms or sublimations of their creators' pathologies. While Freud's approach to aesthetics is generally admitted to be naive and reductive, his initial treatment of the work of art as symptom remains in psychoanalytic approaches to cinema, even if they follow in the wake of Lacan's more complex and structuralist-inflected theories of the unconscious. Christan Metz, for example, treats the cinema as an 'imaginary signifier' (Metz 1977), which the theorist must take a distance from, and this was later elaborated by more politically engaged theorists who saw the cinema as a gigantic machine for the production of capitalist subjectivity. Similarly in Luara Mulvey's 'Visual Pleasure and Narrative Cinema' (Mulvey 1989), the cinema is an apparatus that, in an Althusserian sense, interpellates subjects according to the binary of sexual difference and which 
is directly tied to the reinforcement of patriarchal values and power relations. In both these cases cinema in general and individual films are treated as the sick patient to be cured by the superior knowledge or discursive strategies of the analyst who refuses to be seduced by cinema's wily pleasures. This approach, not only to cinema but to aesthetic texts in general, extends well beyond psychoanalytic approaches and constitutes a generalised 'hermeneutics of suspicion' in relation to cultural objects that is merely intensified in relation to the mass semiotic machinery of the cinema, whose mass appeal to popular audiences rendered it that much more suspect in the eyes of many critical theorists.

It is against this kind of approach that Deleuze developed the idea of the work of art as a symptomatology rather than symptom, by means of which the artist diagnoses both him or herself and the world. First developed in Deleuze's presentation of Sacher Masoch's Venus in Furs (Deleuze 1989b), this idea can be seen as the first principle of the collection of essays entitled Critical and Clinical Essays (Deleuze 1997). In both these instances what is challenged is the medicalisation of art and the artist in favour of an affirmation of what Felix Guattari would call aesthetic cartographies. In the case of Sacher-Masoch and de Sade, these authors were taken at face value by Krafft-Ebing and subsequent psychologists and their works seen as transparent windows onto the world of sadomasochism. Deleuze's critique of this medicalised reading practice is twofold: firstly, any full attention to the texts of the two authors will reveal that their works present entirely different universes rendering it illegitimate to conflate them into a single sadomasochistic syndrome (Deleuze 1989b, 13). More importantly, what this reading strategy demonstrates is the medical treatment of works of literature as symptoms that are then projected onto their authors who are seen as prime sufferers of the syndrome they present in their works. Instead, Deleuze argues that they should rather be seen as clinicians who identify and diagnose signs, that is to say symptoms, 'the physician of themsleves and of the world' (Deleuze 1997, 3) . This not only reiterates the well-known defense of de Sade from charges of sadism by Bataille and others since, as Deleuze points out, a true sadist would rather conceal the dynamics of sadism by using 'the hypocritical language of established order and power' (Deleuze 1989b 17), but also argues against the reduction of Sacher-Masoch's work to a mere clinical curiosity. Turning the medical gaze against itself, Deleuze claims that these authors present to us an exalted 'pornology' (18), a form of knowledge that doctors and psychoanalysts should learn from, instead of reducing these works and their authors to mere symptoms. A truly 'critical and clinical' approach to aesthetic works would then treat them less as pathological symptoms than as the critical diagnosis of forms of subjectivity or subjectivation processes. This does not mean that these authors do not have any experience of the pathologies that populate their works but rather that by going to the end of confronting and mapping these symptoms, they express what Deleuze calls the 'great health' of the artist (or philosopher since he includes Nietzsche and Spinoza in this), who returns from his visions with 'bloodshot eyes and pierced ear-drums' (Deleuze 1997, 3), like Kafka's 'swimming champion who does not know how to swim' (2). The importance for this article of this reversal of perspective in the critical and clinical analysis of aesthetic objects is that it informed not only Deleuze's project but also the work of Félix Guattari and later that of Berardi. While Deleuze's apparent auteurism can be seen as a type of shorthand for identifying particular arrangements of cinematic signs, it was in the work of Felix Guattari, who had a much greater practical and theoretical predisposition towards groups, that the possibilities of cinema as a minor, symptomatological art are further developed. 


\section{Cinema as a Guattarian Aesthetic Cartography}

As Gary Genosko has indicated (Genosko 2009, 134), Guattari devoted frustratingly few pieces of writing to the cinema or individual films, yet what he did write is exemplary in its use of a symptomatological approach, relatively free of Deleuze's vestigial auteurism. This is particuarly apparent in the short essay, 'The Poor Man's Couch’ (Guattari 1996, 155-166), in which Guattari claims that cinema provides a type of mass equivalent of the psychoanalytic cure. For this reason psychoanalysts are singularly unable to grasp cinematic symptomatologies since the cinema constitutes 'a normalisation of the social imaginary that is irreducible to familialist and Oedipal models' (155). The shift from the reductive Freudian readings of semantics to the Lacanian strucutralist readings in terms of the signifier are, for Guattari, no great advance in psychoanalytic attempts to diagnose the cinema. Disputing especially Metz's approach to the cinema as being structured in a similar manner to the Lacanian unconscious 'like a lanugage' through an assembly of syntagmatic chains, Guattari argues that cinema's 'montage of asignifying semiotic chains of intensities, movements and multiplicities fundamentally tends to free it from the signifying grid' (161). This is not to say that Guattari has a utopian view of cinema, which he in fact says is just as repressive as psychoanalysis, only in a completely different manner. What cinema, at least in its commercial forms offers is a machinic, 'inexpensive drug' (162), that in its own way works on the unconscious. Instead of paying for a professional witness as in psychoanalysis, at the cinema, the audience pays less money to be 'invaded by subjective arrangements with blurry contours ... that, in principle, have no lasting effects' (163). In practice what is enacted does have effects in that it models forms of subjective mutation, which remain as traces of the cinematic session, just as do other narcotics. As a machinic narcotic, cinema is a giant and much more effective process for the production of normalisation than the psychoanalytic cure but paradoxically it does this via a process of complete subjective deterritorialisation. For this reason, cinema is both 'the best and the worst' that modern capitalist societies offer their subjects and contains within its machinic production of subjectivity liberating potentials: 'a film that could shake free of its function of adaptational drugging could have unimaginable liberating effects on an entirely different scale to those produced by books' (164). This is because cinematic language is a living language that while for the most part turned towards repressive ends is uniquely able to capture and express processes of psychic semiotisation and therefore could become 'a cinema of combat, attacking dominant values in the present state of things' (165).

Elsewhere, Guattari develops his own conception of minor cinema, related to but distinct from Deleuze's elaboration of this field. As Gary Genosko has pointed out $(2009,134 \mathrm{ff}$.) with both authors this is both related to and distinct from theoretical and practical elaborations of third cinema and in Guattari's case certainly takes a distance from doctrinaire positions and narrow definitions of worthwhile modes of cinematic production. Guattari's examples range from obscure anti-psychiatric documentaries, to the works of nascent American auteurs like David Lynch and Terence Malick, an eclecticism that also informs Berardi's use of cinema. What Guattari's cinematic examples share is that in his reading of them, they all elaborate nonnormative processes of desire, capable in principle of countering the normalisation processes of both commercial cinema and psychoanalysis. For example, Guattari indicates several examples that could constitute a cinema of anti-psychiatry or sees in a film like Malick's Badlands (1973), a profound process of 'amour fou' or schizo-desire worthy of the best productions of the surrealists (Guattari 1996, 167-176). But perhaps the most interesting reading of cinema as a symptomatology that Guattari presents is in relation to the compendium film, Germany in Autumn (1978); since Berardi also engages with this film it is worth looking at Guattari's reading 
of the film in more detail before passing onto Berardi's telegraphic account of the film.

Guattari's piece on the film is entitled 'Like the Echo of a Collective Melancholia' (181187). This title already indicates that this is not at all a question of even multiple authorship but of a collectively produced work that furthermore expresses wider collective affects and subjective responses to the events surrounding the Baader Meinhof/Red Army Fraction's actions, the 'murder-suicides' of its leaders in prison and the corresponding intensification of state repression and policing. Guattari points out that the collective dimensions of the film go beyond being the work of multiple directors but was the result of common elaborations and was made in the heat of the moment under the impact of the 'terrorist events' themselves. ${ }^{1}$ What Guattari especially admires in the film is the attempt on the part of its makers to resist the media intoxication surrounding the events, that the 'terrorists' themselves also contributed to as well as what he calls the media's 'infernal machine of guilt-inducement' (182). For Guattari, Rather than dealing with the sphere of ideology in which positions and opinions have already become hardened, the film 'questions the collective emotional context in which these opinions take shape' (183). In relation to the abhorrent media spectacles engineered by the RAF from the inane replication of bourgeois justice to staging skyjackings as a media event to the (mis)treatment of fellow travellers, the film Germany in Autumn gives a sympomatological response, critical of all sides of this situation (the RAF, the state, the media) even if for Guattari, the film is still too timid in its critique of the actions of these self-appointed vanguard movements. This kind of symptomatology is presented by Guattari as a powerful weapon and an essential one if any really profound political change is going to occur, since it is a singular expression of desire that acts directly on subjective mutations, rather than relegating subjectivity to a mere epi-phenomenon of conflicting ideological positions.

\section{Berardi and the Cinema of 77: Cinematic Late Modernism, Germany in Autumn and The Serpent's Egg}

In Precarious Rhapsody, Berardi also deals with this film if only very briefly, along with a range of other events taking place in 1977, including the explosion and repression of the Autonomia movement in Rome and Bologna, the punk phenomenon, the beginnings of Apple, the already mentioned terrorist events and even such events as the death of Charlie Chaplin which takes on the implication of the death of modernity itself. For Berardi, the film 'tells of the widespread perception of the coming end of social solidarity' (2009a, 16). He sees in the film a type of fog descending on political life, and a situation in which Stammheim becomes a metaphor the 'everyday jail' that is spreading throughout social life (16). Apart form its extreme brevity, this reading of Germany in Autumn contrasts with Guattari's approach to the film in many respects: in the place of a courageous project in common that diagnoses and resists a contemporary condition, in other words a symptomatology, we have the film being treated as a symptom, a metaphor of the hardening of political life begun in 1977 and continued subsequently with the dual implementation of Neoliberal economic policies and digital technologies. Berardi's reading seems a Foucauldian one of seeing in the film an emblem of carceral society at the very point in which from of power and control were transforming themselves, while forms of resistance were

1 For a more detailed treatment of this film and Guattari's treatment of it in relaiton to Fassbinder's relation to ‘terrorism', see Michael Goddard and Benjamin Halligan (2010), ‘The Autumn in Germany: A Dialogue on Fassbinder and Terrorism', in Fabio Vighi and Alexis Nouss ed. Pasolini, Fassbinder and Europe: Between Utopia and Nihilism. Newcastle: Cambridge Scholars Press, 151-170. 
becoming exhausted. No doubt the differences between hindsight and a contemporary response are part of the explanation and surely Guattari's view of the film, after the 'years of winter' of the 1980s would also have been reconfigured. Nevertheless, in the treatment of this film, telegraphic though it is, it is hard to see anything other than a quite conventional treatment of it as a symptom of its time rather than a symptomatology capable of explaining it.

It is a little unfair to concentrate on this example, however, since there are other instances in which Berardi's approach to cinematic cartographies does indeed attain the level of symptomatology. There is a definite continuity here with Deleuze and Guattari's interests in minor cinema, in Berardi's work often associated both with minor works by major directors, as well as with films produced in non-Western, mostly Asian, locations. Berardi's examples, unlike Guattari's, tend not to be forms of militant, documentary or anti-psychiatric cinema, which is partly explicable because of the disappearance and marginalisation of these cinematic practices. However, what Berardi is interested in are films that map subjective mutations in relation to digital technologies, post-fordist transformations of labour and the implantation of cognitive capitalism, which tend to be located in more mainstream films, even if these cartographies do not engage with Hollywood blockbusters.

In the third chapter of The Soul at Work, 'The Poisoned Soul' (Berardi 2009b, 106-183), cinema is first introduced as a corollary to Berardi's treatment of alienation as a now surpassed or reconfigured problem of modernity. Two films, which could be seen as exemplary of late cinematic modernism, namely Antonioni’s Red Desert (1964) and Bergman’s Persona (1966), are used as diagnoses of subjectivity in the last years of the industrial era. Nevertheless the treatment of these films is as more than mere symptoms but as complex readings of the times of the 60s in which they were produced. In Red Desert what Berardi admires is that the film not only depicted the malaise associated with industrial spaces and alienated social relations but that it succeeded in 'representing a passage that is not simply related to culture and politics but first of all to the sensibility and quality of emotions' (110). This is not unlike Deleuze's characterisation of Antonioni as the filmmaker of the 'chronic' in the double sense of both a transformation in the experience of time and a chronic experience of spiritual malaise. Berardi situates this rightly in the bourgeois milieu prior to 1968 in which the diagnosis of the coldness of private relations was one of the factors leading to the public explosion of 1968. What Antonioni shows, through his use of flattened pop art 'flat interiors and desolate industrial exteriors' (110) is an industrialisation not only of exterior spaces but also of subjective existence, which undergoes a similar flattening and homogenisation.

In a different yet related way, Berardi sees in Bergman's Persona a similar study of contemporary alienation that goes beyond any individual psychopathology to a deep cultural malaise. Again it is a presentation of cultural incommunicability and reification in which the person is submitted to the thing (111). In this respect it is surprising that no mention is made of the machinic elements in Persona such as the child's hand on the giant screen at the beginning of the film or the burning through of the film-strip later in the film which are highly suggestive of a reflexive interpenetration of cinema, technology and subjectivity. Nor does Berardi refer to the scenes watched on television related to the Vietnam war, specifically of the Buddhist monks' political acts of self-immolation, which not only situate the subjective drama in relation to political movements to come but also serve to extend its presentation of silence and aphasia beyond a strictly personal and into a world-historical context. Much of this is, however, implied when Berardi treats the rarefying of human communication in the film as a 'cipher of the human ambience that was brewing in those years' (110). While both these films are acknowledged as symptomatologies of their time, their treatment remains unsatisfyingly condensed and still on the 
borders of a being a mere illustration of a cultural condition of reification and subjective malaise rather than a full symptomatology of these conditions, even if they are presented as sowing the seeds for the new forms of post 1968 social relations that would render their depictions of (bourgeois) alienation almost obsolescent.

There is a far more interesting treatment, however, of another Bergman film, The Serpent's Egg (1977), again in the context of the year 1977 as a crucial axis of transition between fordism and post-fordism. As Berardi acknowledges, this film is generally considered a minor one in Bergman's career and even Bergman himself refers to it as an artistic failure: 'I wrote that the artistic failure of The Serprent's Egg was due mainly to the fact that I set the film in 1920s Berlin ... now I believe the failure lies much deeper' (Bergman 1994, 190). Interestingly, given Berardi's theses on the digital era as being characterized precisely by the excess of stimuli, messages, pharmaceutical intake and demands for constant attention to multiple data flows, Bergman further qualifies the failure of the film not as lacking something but in terms of a similar perceptual excess, 'It is overstimulated, as if it had taken anabolic steroids' (190). For Bergman there was 'too much' in the film meaning that the story he wanted to tell about two trapeze artists who are stranded because the death of the third member of their act has died was contaminated by taking place in the actual historical city of Berlin on the eve of the Nazi seizure of power. Nevertheless it is this contamination between these interpersonal relations and their decay and the historically situated decay of Berlin in the 1920s that makes this minor Bergman film so interesting and connects up its affective dynamics with world historical forces. In Precarious Rhapsody, Berardi states that viewing The Serpent's Egg at the end of 1977 it seemed to speak directly to his generation's political experiences and provided 'a very interesting insight in[to] the construction of the totalitarian mind' (2009a, 15). The film's reference in the title to the serpent's egg of Nazism 'slowly opening' (16) seemed highly relevant in in a context in which the repression of Radio Alice and the Autonomia movement was similarly accompanied by 'the smell of a new totalitarianism in the making' (16). In other words, rather than seeing the film as an accurate or otherwise portrayal of the proto-Nazi era in Germany in the 1920s, the film functioned for Berardi as an accurate symptomatology of the present, precisely because it traced the emergence of totalitarianism on a virtual, affective plane, at once abstract and concrete, that was not limited to a specific historical representation. This perhaps echoes what Bergman had originally hoped from the film and yet paradoxically it only works this way because it is grounded in an actual historical period from which it is able to extract the signs of a more general process, relevant also to the present, that is it functions precisely as a symptomatology.

In The Soul at Work, this approach to the film is expanded and Berardi goes as far as to claim that the film 'opens the way to a new definition of historicity ... redefining alienation as a material, chemical, or rather neuro-chemical mutation' (112). In other words, something happens to Bergman's earlier diagnoses of alienation and incommunicability in films like Persona which is more than the mere fact of placing the affective relations in a specific historical context. The Serpent's Egg operates on a chemical or molecular level prior to the actual emergence of fixed ideologies or even emotions, instead tracking their processes of constitution as a type of chemical pollution of the collective mind. What is crucial about the film is that precisely because it operates at this molecular level, the processes it discerns are applicable to other types of mental pollution such as by consumerism, competitive conformism or religious fundamentalisms. It is perhaps surprising that Berardi makes no reference to Wilhelm Reich's The Mass Psychology of Fascism which not only attempted a similar analysis of the mental processes that enabled the emergence of Fascism but was also a key reference point for Deleuze and Guattari's concept in Anti-Oedipus of the co-extensiveness of desire with the social field, albeit one with some 
shortcomings (Deleuze and Guattari 2004, 31). If Berardi prefers Bergman's 'artistic cartography' of this phenomenon to Reich's psychoanalytic one it is perhaps precisely due to the retreat on Reich's part from the full implications of this co-extensiveness of the fields of desire and the social which in some respects the film presents in a better way as a poisoning of affective relations at a molecular level rather than as a mass ideological process. Berardi refers to a crowd scene in the film in which 'the social body is transformed by Nazism into and amorphous mass ... ready to be led' (112). But this is shown in the film via slow motion and expressive deformations of colour, less as the actions of a persuasive ideology than as a growing environmental toxicity that leads the social over a pathological threshold in the manner of a chemical reaction.

The title of the film refers to a speech by Brutus in Shakespeare's Julius Caesar in which the latter is likened to a serpent's egg in order to justify his killing not for the evil that he had already committed but for what he would do, given absolute power in other words as type of preemption. On a simplistic level then the film might imply the situation in which Hitler and Nazism could have been resisted before the seizure of power made any such resistance much more difficult if not impossible. But the film does not focus on this level at all but rather on the symptomatology of this virtual process of the poisoning of social relations prior to their political or ideological results. As such it treats incommunicability and alienation not as a metaphor but as a psychopathological process 'spreading on a social scale' (113). This is what renders the film's presentation of alienation as at once psychic and social, material and affective with a direct relationship between these spheres. This is precisely the operation of a symptomatology since symptoms experienced by individual characters are not presented as disconnected individual symptoms but as signs of an emergent social psychopathology that a more historicist or even psychoanalytic analysis would mask through processes of representation and metaphor. Again Berardi insists that this film was not primarily about the past but the present or rather the future that was emerging at its time of production in 1977 and that is now our present, the complete inter-penetration of subjective life by market forces, info-productive stimulation and the languages of advertising and consumerism that operate on us 'like a nerve gas' (113). Berardi is not equating contemporary Neoliberalism with Nazism but rather insisting that the subjective mutations it has unleashed are even further reaching and more profound, since it operates directly on the virtual level of modulating affect and sensibility or what Berardi calls 'the biological and cognitive texture of society' rather than on 'superficial behaviours' (113). This is already quite a lot to find in a film considered even by its director as a failure but it is this very failure that perhaps allows the film to operate on a minor register that is able to directly link up affective and historical processes, the material and the immaterial, in a similar manner to Kafka's work to whom the concept of the minor was first applied by Deleuze and Guattari.

In a similar vein, Berardi turns later on in the same chapter to a 'minor' work by Wenders, Tokyo-Ga (1985), in which he sees as indicating a possible artistic or even therapeutic approach to the contemproary situation of enchained desire, the emergence of which was so well diagnosed in The Serpent's Egg. Like Bergman's film, Tokyo-Ga is usually considered as a minor one but Berardi situates it as a key point of transition between the 'dreamy, slow and nostalgic narration' (143) of Wenders 70s cinema and his later 'conflicted but fascinated use of electronic technologies' (143), especially in Until the End of the World (1991). The real precursor, however, to Tokyo-Ga is Lightning over Water (Nick's Film) (1980) a film in which Wenders acted out his attachment to the work of the dying director Nicholas Ray by making a documentary on him whose production is shown to be possibly detrimental to Ray's health or even precipitating his death. In Tokyo-Ga, these dynamics are reversed since it is not merely a matter of calling up the dead but also the disappearance of an entire world of which nothing remains except Ozu's films 
and some of his collaborators.

The search for Ozu then becomes the chronicle of a disappearance that at the same time presents contemporary hyper-modern Japan in the old-fashioned form of a journal of impressions, thoughts and emotions. For Berardi, Ozu's cinema not only belongs to the now vanished society of pre-war Japan but also involved a human use of technology whereby it was able to extend traditional modes of perception and experience while at the same time respecting them, hence the stationary shots of traditional environments that seem to relegate modernity to an unobtrusive backdrop. Wenders' camera, however, reveals a totally transformed world in which these human technology relations have been reversed so much so that human sensory perception becomes the effect of a global panoptic gaze in world of generalised simulation, in line with contemporary theories of the time such as Baudrillard's. For Berardi, the Japan presented by Wenders is one in which an 'artificial mutation has occurred: the world is nothing but a simulation effect' (144). Included in Wenders' inventory are simulated objects like the artificial food that is created to advertise the wares of restaurants, to simulated social activities such as rooftop golf driving ranges in which the imperial open-air sport is transformed into a solipsistic leisure activity for salarymen for whom both space and free time are limited. Even more than this Pachinko is singled out as a reified activity, at once individual, isolating and collective which, as Barthes had already pointed out, resembles nothing so much as working on a production line. While all of these accounts run the risk of a residual Orientalism, what justifies it in Wenders' film is a shared experience between Germany and Japan of a traumatic, unassimilable war-time past, from which some kind of escape route needs to be found; in West Germany via rock music and American movies in Japan via pachinko (even if American popular culture played a decisive role in both contexts).

For Berardi, Wenders film presents hyper-modern Japan under the sign of the void which is 'not the void that Zen Buddhism talks about, or not only that' (146). Rather using film history as a cartographic tool, Wenders is able to point to the emergence of a new kind of void, not at all like the emptiness and space for meditaiton in Ozu's films provided by the famous 'pillow shots' or still lifes that Deleuze discusses in Cinema 2. This new type of void, acocording to Berardi, belongs no longer to the world of Ozu but to 'the Demiurge of simulation' (146). In other words what Wenders discerns in contemporary Japan is precisely the world of simulation and derealisation as described by Buadrillard and this is precisely what Berardi goes on to discuss. At this point, however, a question could be raised as to whether Wenders' film was the most useful cinematic cartography to use either for its presentation of contemporary Japan or the derealised world of simulation in general. Chris Marker's Sunless (1982), for example, is a much more nuanced engagement with the same context and one that is far less tainted by European romantic orientalism or such a Manichean view of the mutations brought about by simulation technologies. In Marker's film, for example, there is the idea of multiple co-existing temporalities as a way of understanding cultural differences as expressive of different rhythms that may render seemingly bizarre or inexplicable observations if not understandable then at least referable to a different temporality which one must approach with sensitivity before simply interpreting in a western framework. While Wenders acts as if he somehow knows Japan via the films of Ozu, Marker foregrounds his position as an outsider, a traveler, who can only assemble and reflect on images, rather than gain direct access to an ontological truth. From this perspective the technologisation and implantation of simulation technologies, which Marker tracks through fairly similar phenomena to Wenders but is more prepared to follow their different rhythms rather than constantly comparing them to the ideal presented by Ozu's cinema, an ideal which after all has never existed as such even in pre-war Japan. This becomes apparent in Marker's fascination with 
the inventions of new modes of video imagery which are being developed in Japan, a far more fruitful area of engagement than simulated food or golf, since it refers to the imminent transformation of visual regimes that Wenders would later investigate in Until the End of the World. There is a kind of self-indulgent perversity in Tokyo-Ga in Wenders' drive to find traces of the world of Ozu in Tokyo, as if such a world ever existed except in a Western cinephile fantasy of Japan that is entirely lacking in Marker's film which instead sees in Japan a new constellaiton of both innovation and tradition, old and new forms of temporality, which he locates on a global plan that also takes in Africa and Europe, as well as Japan. The post-human dimension diagnosed in Wenders film is at the very least a problematic one, at least partially generated by cinephile projections of an idealised nostalgic past and the assimilation of Japanese post-war experience to that of an exoticised Germany. This is brought out especially in the conversation between Wenders and Herzog in which the latter maintains that it is not only impossible to make films in Europe or America but virtually anywhere on the globe since everywhere has been ruined by the civilisation of the image. For these reasons, while Berardi is able to bring out what the film does, despite its limitations, show of the mutation of subjective experience under post-industrial conditions, neither Wenders' film, nor Berardi's treatment of it provides as rich a symptomatology as his treatment of The Serpent's Egg.

\section{Contemporary Cinema as Symptomatology: Elephant and Still Life}

Berardi's engagement with cinematic cartographies are not, however confined to the works of European auteurs or to what is now part of film history but instead have engaged with several contemporary exmaples of both film and video art. Amongst these examples, Gus van Sant's Elephant is one that is treated as a contemporary symptomatology of Neoliberal societies under the implementation of digital technologies in the affective realm but he also significantly refers to several films of an Asian provenance as similarly tracking contemporary affective and cognitive mutations, particularly Zhang Ke Jia’s Still Life and Kim Ki-Duk’s Time (2006). These contemporary cinematic examples are accompanied by engagements with video art, advertising, digital pornography and even the uses of the media on the part of homicidal/suicidal killers, sometimes but not always on a similar symptomatic rather than symptomatological plane.

Elephant is discussed in the 'Frail Psychosphere' chapter of Precarious Rhapsody as providing a much better account than Michael Moore’s Bowling for Columbine (2002) of the psychopathological conditions capable of generating Columbine style murder-suicide events, among what Berardi refers to as the digital-connective generation. While the discussion of the film is brief it is very significant since the chapter will go on to elaborate the mutations or even destruction of sensitivity and and sensibility that for Berardi characterise the digital era, as expressed in the symptomatic forms of digital pornography, 'torture porn' and killer videos. Like The Serprent's Egg, Elephant probes beneath the surface of contemporary destructiveness, avoiding readymade answers to the questions of the mental conditions facilitating the eruption of mass murder in an ordinary high school. In Elephant, the banal events of an 'ordinary' day are followed until it is revealed that this day is not so ordinary and that two of the teenagers shown are about to kill as many as possible of their classmates and teachers. However the brutality is not limited to these acts but pervades all the relations shown in the film through a generalised atmosphere of disconnection and malaise that effectively updates the one shown in Bergman's films. Berardi gives the example of the 'relational incompetence' shown in the dialogue of three female friends intent in quantifying the amount of time required to spend with a 'best friend' when one has a boyfriend thereby enacting a total reduction of social relations to a banal 
algorithm. Admittedly there would be some counter examples such as the creativity represented via the interest in several of the teenagers in photography but this is presented as a weak resistance to the general atmosphere of disconnection. More poignantly the seemingly endless corridors of the high school are shows as a non-space in which relations are reduced to the judgments of 'looks' in the sense of both appearances and a vacant gaze in which those of the prospective killers are not so different from those of their classmates. For Berardi this is a symptom of a transition from what he calls conjunction to connection in which direct, imperfect and unmediated contact has been replaced by virtual connections at a distance so that the difference between playing a violent video game and playing it out in real life with one's neighbouring human beings is only a difference in degree not in kind. This decline in the contact with the other results in what Berardi calls 'a peripheral massacre-reproducible, replicable, contagious' (86) not so much a tragedy or exceptional event as an index of a world in which images of sexuality and brutality circulate as an everyday banality with little distinction between them. What Berardi admires in Elephant which is lacking in Bowling for Columbine is the symptomatology of the cognitive mutation gripping the video-electronic generation in which the functionality of connection leads to an atrophy of affect and sensitivity to the other which are the pre-conditions for such an everyday massacre to occur.

Berardi's discussion of Still Life takes place in a different context, that of $21^{\text {st }}$ Century dystopian art in which the late $20^{\text {th }}$ Century literary dystopias of Burroughs or Phillip K.Dick have now occupied the entire space of artistic imagination in film, video art and literature but now without any sense of an outside or any alternative future. In this dystopian context, Still Life stands out as a unique depiction of the effects of Chinese capitalism, in its presentation of the main character Huo, who is searching for his family amid the architectural and social wreckage caused by the three gorges dam project. Not only has his riverside village been destroyed but so has the entire social fabric so that the only available form of employment is to participate in completing the destruction of the villages initiated by the building of the dam. The film therefore provides a portrait of 'submerged life' that is at once surreal and the most realistic portrayals of the operations of contemporary Chinese capitalism, through the destroyed environment unleashed by the dam, itself a microcosm of the violence of neoliberal capitalist transformation. If the dystopian aesthetics of Zhang Ke's film as well as Jonathan Franzen's novel, The Corrections, are still treated as symptomatologies they are nevertheless seen as powerless ones and this is even more the case with Berardi's treatment of video art. While the work of Eija-Liisa Ahtila is reduced to the psychopathology of relations, the inability to touch and to be touched' (132), Yakizakana no Uta/ The Song of the Mackerel (2004) in which a fish about to be eaten keeps happily chatting to the student who will eat it all the way from the supermarket shelf to the plate, is presented as a pure symptom of the powerlessness of contemporary art to be anything except confirm the contemporary dystopian condition by navigating a path between cynicism and irony 'that allows them to suspend the execution at least for the moment' (135) but necessarily devoid of any desire for rupture or resistance.

\section{Conclusion: The Social Network as $21^{\text {st }}$ Century Symptomatology}

This bleak account of contemporary artistic production and especially of video art is the direct result of a Manichean approach to the subjective mutations unleashed by digital processes that proceeds by abandoning the symptomatological approach that had been accorded to earlier cinematic works, instead seeing the works of video art as mere symptoms of the their dystopian times. This can be seen in the strong distinctions Berardi makes between conjunction and connection and between the modern, cinematic order of expression and reproduction and the 
contemporary order of simulacra and synthetic images. This is a recapitulation of Baudrillard's (anti) postmodern stance that may be similarly blind to the more nuanced aspects of contemporary subjective mutations in the digital-connective era. Relegating artistic cartographies to a position of powerlessness may reflect a relative decline in the belief in their effectiveness or subversive powers, relative to the Twentieth Century avant-gardes but it is too drastic to see in contemporary artistic, cinematic and media art practices nothing more than futile gestures of temporary survival. While Berardi's readings of some of the cinematic examples mentioned are at times nuanced and fascinating, the readings of video art as presented in Precarious Rhapsody are violently reductive, missing the subtleties of Athila's work on mediated subjectivities and providing a too metaphorical reading of Song of the Mackerel that at the same time underplays its humorous and ecologically post-human dimensions.

A final cinematic counter-example can be given that calls for a fully symptomatological reading, namely David Fincher's recent film, The Social Network (2010). Just as his earlier film Fight Club (1999) gave a depiction of the Millennial affective unease that seemed to prefigure events as diverse as the alter-globalaisation movement and the 9/11 attacks, The Social Network provides a visualisation of a 'history of the present' that is so far yet to be represented. The fact that the film is largely based on the sensational novelisation of an at best partial account of the events leading to the formation of Facebook is of no consequence since the film is less concerned with this history as such, as much as what it is able to reveal about contemporary social exsistence and the implementation of its mediation via technical networks. In the opening scenes, Mark Zuckerberg is presented as at once highly relationally dysfunctional and hyper-functional cognitively as he seems to be simultaneously processing four or five distinct data streams in what should be a straightforward conversation. Clearly this embodies the dynamics of Facebook and other forms of technical social networking in which the modulation of multiple data streams comes to replace focused attention on a specific interlocutor. Mark, continues throughout the film to experience problems of attention although often this is less a problem for him than for those seeking his attention, as when, for example he is far more concerned with a note condemning him for his FaceSmash Website than a computing problem that he nevertheless casually solves as exiting the class-room, or tells a lawyer at one of the litigation hearings exactly how miniscule an amount of attention he is affording his questions.

The relations in the film are grounded in the elite context of Harvard and shown as a clash between the old moneyed elite and the predominantly Jewish or otherwise ethnically other geeky programmers who seem universally to aspire to the social status of the former. However, whereas Mark's best friend Eduardo aims to infiltrate this closed world via perfected competitive conformity, Mark thinks that his powers of invention will provide a shorter route via notoreity: a conflict in subjective adaptation that structures the entire film with Sean Parker, played by Justin Timberlake at the extreme of the unconventional pole and the Winklevoss twins at the extreme end of a competitive conformity whose extremity shocks even their peers. This is far from constituting anything like class conflict given that at issue on level is merely a question of who gets access to being part of an economic and cultural elite, as seen through the desires of already privileged college students. However, this internecine conflict at the heart of the constitution of contemporary social networks is precisely captivating because its effects so far outstrip their causes. What the film shows is how from entirely banal motivations a process of invention is unleashed, beyond the wills and intentions of any of its contributors that ends up capturing the entire field of social relations. That this is done as blankly as possible is both a reflection of Mark's asociality and a kind of genius for abstraction that was no doubt the key to Facebook's success, humorously dramatised in the film when Sean gives the advice to drop the 'the' of 
Facebook so it will be 'cleaner.' The result is a film that resembles in many respects Welles' Citizen Kane (1941), in its demonstration of the ruthless development of a media empire which ends up betraying any initial idealism it might have had to become a pure expression of capitalist forces. Except between the $20^{\text {th }}$ and $21^{\text {st }}$ Centuries media have become both globalised and minituarised, so that in the place of the gigantic figure of Kane, shot from below in the manner of a great dictator, there is only a small geeky innovator whose social incommunicability is only transcended for the occasional brutal put down and for whom non technically mediated communication is presented as a painful experience.

While this account of the film might seem to confirm Berardi's dystopian view of the powerlessness of contemporary artistic cartographies, the sheer joy and energy of the film acts against this; it is as if despite everything shown in the film as well as the later aspects of Facebook such as its intensive use for data mining and the very commercialisation which it was supposed in the beginning to escape, what the film is really about is the power of invention itself and more specifically the socialisation of contemporary digital technologies. It implies both a critique of all sides of the conflicts over the ownership of the site and their respective subjective modalities and hints that the actual use of Facebook and similar tools might and should go beyond the limitations of its creators. At the very least it provides a convincing genealogy of one aspect of contemporary communicative capitalism, a symptomatology of the present that might open up new possibilities for subjective, cognitive mutation beyond a purely capitalist, competitive framework. Needless to say, there are numerous other recent films that could be just as amenable to such a symptomatological reading including Lars von Trier's The Boss of it All (2006) and Ulrich Seidl's Import-Export (2007) both of which function as powerful symptomatologies of new modes of labour and the production of subjectivity in the respective contexts of a small 'non-herarchical' IT firm and the still existing economic boundaries between Eastern and Western Europe.

This article has explored the idea of cinematic cartography as a form of symptomatology and shown its operations in Berardi's recent work. As such it deals with an admittedly minor aspect of Berardi's work, but an aspect that is very much tied up with the concept itself of the minor, in the sense of cinema constituting a minor art as Deleuze, Guattari and Berardi have all, in different ways, proposed. This minor perspective on Berardi's work is an illuminating one, both in terms of its strengths and weaknesses, the former evident in his brilliant reading of Bergman's The Serpent's Egg, and the latter most apparent in his cursory engagement with works of video art as pure symptoms of aesthetic and affective atrophy on par with 'killer' videos and digital pornography. One can only hope that we will see more use of cinematic and other forms of media art cartographies in the full symptomatological sense both in Berardi's future work and in those who find the inspiration to carry this work further and into other domains. 


\section{References}

Berardi, Franco 'Bifo'(2009a). Precarious Rhapsody: Semiocapitalism and the pathologies of the post-alpha generation. Ed. Erik Empson and Stevphen Shukaitis. Trans. Ariana Bove et al. London: Autonomedia/Minor Compositions.

Berardi, Franco ‘Bifo’ (2009b). The Soul at Work: From Alienation to Autonomy. Trans. Francesca Cadel and Giuseppina Mecchia. Semiotext(e): Los Angeles.

Bergman, Ingmar (1994). Images: My Life in Film.

Deleuze, Gilles (1989a), Cinema 2: The Time-Image. Trans. Hugh Tomlinson and Robert Galeta. Minnaepolis: University of Minnesota press.

Deleuze, Gilles (1989b) ‘Coldness and Cruelty’, Masochism. Trans. Jean McNeil. New York: Zone Books, 7-138.

Deleuze, Gilles (1997). Essays Critical and Clinical. Trans. Daniel W. Smith and Michael A. Greco. Minneapolis: University of Minnesota Press.

Deleuze, Gilles and Félix Guattari (2004). Anti-Oedipus: Capitalism and Schizophrenia. London: Continuum.

Genosko, Gary (2009). Félix Guattari: A Critical Introduction. London, New York: Pluto Press.

Goddard, Michael and Benjamin Halligan (2010). 'The Autumn in Germany: A Dialogue on Fassbinder and Terrorism', in Fabio Vighi and Alexis Nouss ed. Pasolini, Fassbinder and Europe: Between Utopia and Nihilism. Newcastle: Cambridge Scholars Press, 151-170.

Guattari, Félix (1996). Soft Subversions. Ed. Sylvère Lotringer, trans. David L. Sweet and Chet Weiner. New York: Semiotext(e).

Metz, Christian (1982) Psychoanalysis and Cinema: The Imaginary Signifier. Trans. Celia Britton et al. London: Macmillan.

Mulvey, Laura (1989). 'Visual Pleasure and Narrative Cinema.' In: Visual and Other Pleasures. Baisingstoke: Palgrave MacMillan, 14-29.

Reich, Wilhelm (1997). The Mass Psychology of Fascism. London: London: Souvenir Press.

\section{Films Cited}

Antonioni, Michelangelo dir. (1964) The Red Desert.

Bergman, Ingmar dir. (1966) Persona.

Bergman, Ingmar dir. (1977) The Serpent's Egg.

Fincher, David dir. (1999) Fight Club.

Fincher, David dir. (2010) The Social Network.

Malick, Terence dir. (1973) Badlands.

Marker, Chris (1982) Sunless.

Moore, Michael (2002) Bowling for Columbine.

Sakamoto, Yusuke (2004) Yakizakana no Uta/ The Song of the Mackerel.

Seidl, Ulrich dir. (2006) Import-Export.

Von Trier, Lars dir. (2007) The Boss of it All.

Welles, Orson dir. (1941) Citizen Kane.

Wenders, Wim dir. (1980) Lightning over Water (Nick's Film).

Wenders, Wim dir. (1985) Tokyo-Ga.

Wenders, Wim dir. (1991) Until the End of the World. 
